\title{
Towards a Framework of Public Space Governance
}

Zamanifard, H., Alizadeh, T., \& Bosman, C. (2018). Towards a framework of public space governance. Cities.

Please refer to https://doi.org/10.1016/j.cities.2018.02.010 for the latest citation including Journal volume and issue

\begin{abstract}
Public spaces are the loci of complex interactions among multiple stakeholders whose decisions and activities affect places' qualities. The paper builds upon governance theory to provide a holistic indepth approach in understanding the complexity and quality of the place-shaping processes in public spaces. In the absence of adequate conception of governance in urban design and public spaces, the paper introduces a framework for analysing governance capacity of public spaces and applies the framework to a flagship but highly contested public space in Brisbane, Australia namely South Bank Parklands. The proposed framework encompasses four major components of 1) actors and stakeholders, 2) governance structure, 3) governing tools, and 4) governing tasks. The framework puts special emphasis on the contextual factors, the way public spaces are shaped and governed, and political economy of the space. The case study application showcases the applicability of the PSGF which helps holistically analyse the trends in public space governance structure accounting for the diversity and complexity of all elements involved. The findings reveal that South Bank Parklands governance is mix-structured, hierarchical, and highly political. It is, however, a likeable public space for which civic engagement in the decision-making processes is notably limited.
\end{abstract}

Keywords: Public space, Governance framework, Place-shaping, Public space management, South Bank, Australia

\section{Introduction}

Many influential urban thinkers have lamented the decline in qualities of public spaces particularly over their publicness, meaningfulness, social diversity, and authenticity (Lefebvre, 1991; Sennett, 1992; Sorkin, 1992; Tibbalds, 1992). Whether criticisms of the late-twentieth and early-twenty-first century public spaces are founded on idealised conceptions (Brill, 1989; Carmona, 2010; Francis, 1989) or are realistic evaluations, public spaces have certainly changed in many aspects compared with their precedents in pre second World War eras (Banerjee, 2001). The broader societal, technological, political, and economic transformations have caused or triggered changes in public spaces including production, reproduction, and management of public spaces.

Today, many urban public spaces around the world are shaped through contributions of numerous stakeholders and actors such as public organisations and private entities in interrelated ways and complex arrangements (Banerjee, 2001; Madanipour, 2010). Public space provision is not a sole responsibility of governments. Indeed, almost all of the added public spaces in the post-war American downtowns have been provided by the private sector (Loukaitou-Sideris \& Banerjee, 1993). In Australia, UK, New Zealand, and many European 
countries private enterprises are involved in public space delivery or management. This takes place through a number of ways ranging from partnership with the government to having full responsibility for the development, regulation, and management of the space (such as privatelyowned public spaces). Regardless of the reasons, it signals the growing interest of the private sector in urban public spaces contesting the public interest in public spaces. The motivations and agendas of the three main groups of stakeholders of public spaces, the state, the public, and the private are distinctive and more often contradictory. There are also intra-group conflicts between these stakeholders (such as gender or inter-generational conflicts among public users of a space or competition among businesses on the use of space). As a result of these contests, the functions and meanings attached to public spaces change from time to time and across distinctive contexts (Carmona, De Magalhães, \& Hammond, 2008; Pospech, 2013).

Hence, these changes have divided scholars on the basic definitions and expected functions of public space. Dissenting from the private sector involvement and labelling it as privatisation, some have argued that such spaces are not truly public or at best are pseudo public spaces that cannot replace genuine public spaces (Boyer, 1993; Kohn, 2004; Sennett, 1992; Sorkin, 1992). Whereas others argue that the private sector involvement in public space provision should not be seen as a threat to the publicness of space rather as an opportunity for place quality enhancement and better management (Banerjee, 2001; Carmona \& Wunderlich, 2012; De Magalhães, 2010). It is also argued that privatisation would be a simplified conception that does not explain the complexity and nuances of the new redistribution of responsibilities and rights in public space (De Magalhães, 2010). In the absence of adequate empirical research and innovative theories to address the complex and contested nature of public spaces, the conundrum continues to exist.

Studies of public spaces tend to focus on the substantive dimensions of public spaces such as normative theories of good public spaces or positivist stances to the outcomes insulated from shaping processes (Carmona, 2014b; Inam, 2002; Zamanifard, Alizadeh, Coiacetto, \& Sipe, 2016). Studies of the procedural dimensions are limited and mostly fall under what is broadly discussed as 'public space management'. Here, public space management is defined as "the set of processes and practices that ensure public space can fulfil all its legitimate roles, whilst managing the interactions among, and impacts of, those multiple functions in a way that is acceptable to its users" (De Magalhães \& Carmona, 2009, p. 112). Nevertheless, even this line of inquiry falls short of addressing the complexity and multiplicity of stakeholders, their motivations and interests, and their relationship. Concerns on who decides about the legitimate roles of public space, how acceptability is defined and by whom, who are the users and whether they can participate in decision-making processes cannot be effectively argued from the public space management approach (Rakodi, 2003; Ruhanen, Scott, Ritchie, \& Tkaczynski, 2010).

This shortcoming shows the need for the public space literature to adopt more holistic approaches, perhaps through public space governance discourse. Public space governance is not a new concept (see De Magalhães, 2010; De Magalhães \& Freire Trigo, 2017), but its potential for studying public space has not been fully realised. This paper attempts to take a step forward by proposing a public space governance framework (PSGF). The concept of governance, this paper argues, provides a good lens to studying the dynamics of context and 
power in public place-shaping as a collective activity which engages a wide range of stakeholders. The proposed public space framework contributes to understanding the placeshaping processes of public spaces of different types; and sheds light on fundamental aspects of decision-making and power in a holistic manner.

The paper is structured in three sections. First, a review of public space literature is offered. Second, building on the learnings of the literature review, a holistic public space governance framework (PSGF) is proposed and elaborated. In the third section, the proposed framework is applied to a case study public space. The case study application showcases the applicability of the PSGF which helps holistically analyse the trends in public space governance structure accounting for the diversity and complexity of all elements involved. More specifically, the case study findings warn against the trend in which public voice may be further restricted in the decision-making process.

\section{Literature review}

Much of the literature on public space until two decades ago had been focusing on substantive contents such as use, access, and physical attributes; and little work was done on the procedural dimensions of how public spaces were shaped and managed. A reason might be that, in the past, the border between public and private realms were defined in a way that public space provision and management was largely a responsibility of the public entities such as the city councils or governments (Madanipour, 2003). Moreover, public spaces had been considered as a stage or container where certain activities or the spillovers from the adjacent buildings had taken place and those activities had been the focus of procedural studies rather than the space itself (De Magalhães \& Carmona, 2009).

However, the rapidly-growing engagement of for-profit enterprises in shaping publiclyaccessible spaces brought more complexity to the public space debates shifting the focus from substantive and mostly physical attributes to the procedural and mostly managerial aspects. Various forms of partnership between the private and public sectors have been taking place especially in urban settings.

This substantial change in public space provision and its implications for the meanings and functions of the spaces have dividend scholars. In the literature, two distinctive major strands towards private-public partnership in public space shaping can be identified. One bemoans the loss or shrinkage of publicness and public realm and urges for an end to the private sector involvement (Lefebvre \& Enders, 1976; Mitchell, 2003; Sorkin, 1992). The other strand, however, embraces the quality and the quantity that the public-private partnership can add to public spaces (Carmona \& Wunderlich, 2012; Langstraat \& Melik, 2013; Worpole \& Knox, 2008). Below sections elaborate some of the main points made in these two competing strands:

\section{The 'public space privatisation and decline in publicness' debate}

Privatisation conventionally means selling the state property to the individuals or corporations (Kohn, 2004). However, privatised public spaces take multiple forms and degrees and can be defined as publicly accessible spaces majorly owned, developed, and/or managed by private 
enterprises (Carmona, 2014a; Carmona \& Wunderlich, 2012). Privately-owned public spaces such as clubs and shopping malls are the purest form of public space privatisation whereas urban plazas or parks managed by corporations fall at the looser end of privatisation spectrum. The most common kind of privatised urban public spaces in western developed countries are corporation plazas or office parks shaped through some sort of incentive arrangements. That is, the private business frees up part of its land and builds, furnishes, and/or maintains the space that is, by the agreement, accessible to general public and in return receives incentives in forms of special zoning arrangements, larger floor area ratio, rate concession and so on (LoukaitouSideris \& Banerjee, 1993). Nonetheless, other types of public space privatisation happen through gentrification, urban redevelopment, and global capital demands (Mitchell \& Staeheli, 2009). The use of and access to the space is generally controlled and regulated by the private body (Minton, 2006).

The mainstream literature on public space from human geography perspective argues that privatisation of a public space undermines its publicness (Kayden \& Dept. of City Planning, The Municipal Art Society of New York, 2000; Lefebvre, 1991; Lofland, 1989; LoukaitouSideris \& Banerjee, 1993; Low \& Smith, 2006; Madanipour, 2003; Mitchell, 1995; Sennett, 1992). Differentiating between a social space and a public space, Kohn (2004) asserts that private enterprises may be able to create the former but cannot create the latter. She maintains that in a truly public space dissenting people have the chance to meet and so-called undesirables can be seen and their voice can be heard, something that is hardly tolerated by economicallymotivated management regimes. Private control exacerbates exclusion, discrimination, and segregation based on race, socioeconomic status, gender, and age through tangible and intangible policies, semiotic codes, or by structuring people's perceptions and interactions (Goldsteen \& Elliott, 1994; Kohn, 2004). Mitchell (1995, p. 120) argues that privatised public spaces have the tendency to narrow the 'list of eligibles for the public' and exclude homeless people or political activists. Smith and Low (2006) discuss that too much control over public spaces in the US is a consequence of dominant neoliberal discourse on planning that has had negative impacts on democratic politics.

\section{The 'public space privatisation and loss of authenticity' debate}

Sorkin (1992) points out that since the private sector's motivation in shaping public spaces is profit accumulation, there is little room for innovation based on locality and instead similar tested standards and safe rules - theme park variations or Disneyfication - are applied to the design and management of such spaces resulting in homogenised and generic places. Madanipour (2003) resonates with Sorkin but from a different perspective. He concedes that national or international headquarters in the cities in complicity with local governments and driven by market are shaping much of the new urban spaces with regard to certain qualities that would appeal to middle class residents, tourists, capital investment, and consumers and erode local identity. Loukitou-Sideris and Banerjee (1993) observed similar findings when comparing San Francisco and Los Angeles' corporate plazas:

"Urban plazas are designed to be autonomous from their context, unique but fragmented pieces of the new town environment. In that sense urban plazas are a 
reflection of a market-driven-urbanism planned, designed, and packaged to satisfy a predetermined clientele. [...] As such they are quite homogeneous in their form despite differences in the planning style and development process encountered in the two California cities."

\section{The 'public spaces are not in decline but expanding' debate}

On the other hand, there are studies on the regulation of public spaces especially in the US and the UK showing that public spaces have always been highly regulated and never been open to all members of the society (Hajer \& Reijndorp, 2001; Mitchell \& Staeheli, 2009). The publicness of public spaces has been romanticised or idealised (Amin, 2008; Francis, 1989). In fact, it is the mode of exclusion (excluded people) and the right to the space in public spaces that changes over time, while most people would not realise or simply would not care about it. Worpole and Knox (2008, p. 4) in their extensive research of different types of public spaces in the UK argue that 'contrary to conventional assumptions, public space in neighbourhoods, towns and cities is not in decline but is instead expanding.' They state that people use privatelyprovided public spaces such as modern urban plazas, waterfronts, promenades, laneways, passages, and street malls with paying little attention to the ownership or management regimes in place (Worpole \& Knox, 2008).

Moreover, some discuss that the conception of public space as a political space or a space for dialogue between different social groups may not be realistic after all and therefore the concerns with the erosion of politics or diversity from public spaces are typically exaggerated. The middle class tends to avoid undesirables such as homeless people or gangs of teens in public spaces (Light \& Smith, 1998). Many urban commentators and residents think the presence of these marginalised groups is a sign of decline in the public space (Mitchell \& Staeheli, 2009). Research in the US showed that the average American is not generally interested in spending time with strangers in public spaces and prefers entertaining rather than political spaces and avoids places which are culturally dissenting to them (Light \& Smith, 1998).

\section{The 'private sector engagement in public space provision as an enabler' debate}

A line in the literature indicates that the private sector's increasing engagement in shaping public spaces is itself a consequence of decline in public space (Ellin, 1999). Public sector's failure in providing and maintaining quality public spaces in western metropolises over the decades between 1960s and 1990s was heavily criticised for a number of deficiencies that can be put under the umbrella term of under-management (Carmona, 2010). Public spaces were littered, neglected, covered in graffiti, polluted, unsafe (Tibbalds, 1992), invaded by cars and the 'proliferations of fast roads' (Lefebvre, 1991, p. 359), hostile to or unsafe for the female users, children, aging population, and people with disability and the like (Burton \& Mitchell, 2006; Franck \& Paxson, 1989; Malone, 2002).

In the wake of inadequate funding, cities' authorities sought the private sector's help to assist with healing derelict public spaces (Carmona et al., 2008). Therefore, private-public 
partnerships and privately-owned public spaces were proliferated in the UK, US, Australia, Canada, New Zealand and other countries as an opportunity to enhance quality in public spaces.

\section{The gap in the literature: the need for a holistic approach to public space shaping}

The debate around quality vs. publicness is causing a second paradigm shift in studies and conceptualisation of public spaces. A growing body of the literature urges for deeper understanding of public spaces as it is now understood that shaping public space is a dynamic process in which the definitions, rights, expectations, and delivery and management approaches are constantly changing and redefined (see Carmona 2014a, 2014b, 2016a, 2016b; Amin, 2008; De Magalhães, 2010; De Magalhães \& Freire Trigo, 2017; Langstraat \& Melik, 2013; Stevens, 2009).

Placemaking as a promising approach to public space provision became very popular particularly in the praxis of urban design (for example see Friedmann, 2010; PPS, 2000, 2015; Schneekloth \& Shibley, 1995). It majorly focuses on identity, meaning, and place attachment; values bottom-up processes of shaping places; and advocates for community participation. Placemaking, however, is an abstract and normative (it prescribes a special way of making places) prescription for the practice of planning and design. Furthermore, it does not address the concerns with privatisation and rights to the space.

Holistic conception of public space is required that considers quality and publicness alongside with competing interests of different stakeholders. In search of such a holistic approach, human geography and planning scholars turn into to the public space governance discourse (Carmona et al., 2008; Pospech, 2013). Table 1 offers a summary of the literature on urban governance and public space management published in the last three decades. Among studies included in Table 1, two are focal to the rest of this paper. Both studies have been conducted by researchers at UCL's Bartlett School of Planning, (Carmona, 2014b; Carmona et al., 2008).

First, Carmona et al. (2008, pp. 66-67) offers a conceptual framework of public space management consisting of four main components of 'regulation', 'investment', 'maintenance', and 'coordination.' Any management regime, they argue, can be characterised by these key processes of delivery and management. The management's success in regulation, maintenance, and redevelopment is conditioned by the capital and expertise resources it has. The fourth component, 'the coordination of interventions in public space', binds all the other three dimensions and coordinates the activities and agents involved in the management and delivery processes. This framework provides a useful tool for analysing the activities of public space management. Considering management as broad as governance in their framework, Carmona et al. (2008) admit that it is vital to question how the priorities are set, conflicts are resolved, and rights are unfolded in public spaces. However, their framework does not explain the relationships among competing stakeholders in public space shaping process and specifically falls short on clarifying how general public takes part in the process. In addition, the role of different planning and design systems - an important determinant in how a public space is created and used - is not well-elaborated in the framework. 
Second, in a recent work based on an extensive study of public spaces in London, Carmona (2014b) proposed a new theory of urban design process called 'place-shaping continuum'. He founded his theory on time and place arguing that place-shaping is a continuous and dynamic process. Carmona argued that places are either 'shaped for use' or 'shaped through use' meaning that even unselfconscious interventions such as those of ordinary users are part of shaping and reshaping processes of the space. Carmona's model has three layers of power, polity, and place. It puts a great emphasis on the contextual factors, history, and power relationships. The model (Carmona, 2014b, p. 16) suggests four types of place-shaping processes: 'design, development, space (or place) in use, and management' - emphasising that these processes are circular and, in practice, they overlap quite often.

Table 1. Governance and the literature - extracting concepts and aspects that can be used in shaping a public space governance framework

\begin{tabular}{|c|c|c|}
\hline Discussed in & Focus & Governance-related aspects \\
\hline Carmona (2014b) & Urban design & Context; Power; Polity; Actions \\
\hline $\begin{array}{l}\text { De Magalhães and } \\
\text { Carmona (2009) }\end{array}$ & $\begin{array}{l}\text { Public space } \\
\text { management }\end{array}$ & Management models; Management activities \\
\hline Healey $(2010,2015)$ & $\begin{array}{l}\text { Urban } \\
\text { development }\end{array}$ & $\begin{array}{l}\text { Place governance; Socioeconomic conditions; Structure of } \\
\text { power; Civil Society; Stakeholders relationships }\end{array}$ \\
\hline Rhodes $(1997,2007)$ & Governance & $\begin{array}{l}\text { Networks of actors; Relationships between actors; Provision of } \\
\text { public service; Governance variants }\end{array}$ \\
\hline $\begin{array}{l}\text { Pierre }(1999,2005, \\
\text { 2014) }\end{array}$ & Urban governance & $\begin{array}{l}\text { Economic, political, and ideological forces; Models of urban } \\
\text { governance; Overarching objectives; Instruments; Outcomes }\end{array}$ \\
\hline $\begin{array}{l}\text { Coaffee and Healey } \\
(2003)\end{array}$ & Place governance & $\begin{array}{l}\text { Institutional analysis; Social formation; Governance capacity; } \\
\text { Place; Relationships and network building }\end{array}$ \\
\hline $\begin{array}{l}\text { Tiesdell and Adams } \\
(2011) ; \text { Adams and } \\
\text { Tiesdell (2013) }\end{array}$ & $\begin{array}{l}\text { Urban design and } \\
\text { development } \\
\text { process }\end{array}$ & $\begin{array}{l}\text { Actors and stakeholders and their roles in development; Actions } \\
\text { of development and development models; Modes of governance }\end{array}$ \\
\hline Harvey (1989) & $\begin{array}{l}\text { Economic capital } \\
\text { and urban } \\
\text { governance }\end{array}$ & $\begin{array}{l}\text { Urban governance transformation; Economic and political } \\
\text { influences }\end{array}$ \\
\hline $\begin{array}{l}\text { Carmona }(2016 a, \\
\text { 2016b) }\end{array}$ & $\begin{array}{l}\text { Urban design and } \\
\text { governance }\end{array}$ & $\begin{array}{l}\text { Motivations of intervention; Design (in its very broad } \\
\text { definition) quality; Authority; Power; Operation; Governance } \\
\text { instruments; Formal and informal governing tools }\end{array}$ \\
\hline Kent (2013) & Placemaking & $\begin{array}{l}\text { Community capacity; Management; Bottom-up and place-based } \\
\text { action }\end{array}$ \\
\hline Stoker (1998) & Governance & $\begin{array}{l}\text { Conception of governance; Actors beyond government; The } \\
\text { importance of power in the relationships between actors; Self- } \\
\text { governing networks of actors; Governance capacity }\end{array}$ \\
\hline Cuthbert (2006) & $\begin{array}{l}\text { Urban planning } \\
\text { and design }\end{array}$ & $\begin{array}{l}\text { The role of ideology in shaping urban spaces; The links } \\
\text { between urban design and politics }\end{array}$ \\
\hline
\end{tabular}




\begin{tabular}{lll} 
Webster (2007) & $\begin{array}{l}\text { Property rights } \\
\text { and public space }\end{array}$ & $\begin{array}{l}\text { The importance of consumption in governing public space; The } \\
\text { tragedy of commons; Economics of public space }\end{array}$ \\
Hambleton (2015) & $\begin{array}{l}\text { Local leadership } \\
\text { in place making }\end{array}$ & $\begin{array}{l}\text { Outcome (inclusiveness and equity); Good urban governance } \\
\text { traits; Actors (Civil Society, State, Markets); Local government }\end{array}$ \\
$\begin{array}{l}\text { González and Healey } \\
(2005)\end{array}$ & $\begin{array}{l}\text { Institutional } \\
\text { theory and } \\
\text { governance } \\
\text { capacity }\end{array}$ & $\begin{array}{l}\text { Roles of institutions; Relations and interactions between actors; } \\
\text { Arenas; Discourses (framing issues, problems, solutions, } \\
\text { interests); Power structure; Historical and geographical context; }\end{array}$ \\
\hline Practices (activities); Perceptions of actors; Sense of belonging
\end{tabular}

The most striking feature of Carmona's model is that it extends the practice of urban design to unself-conscious interventions of almost every individual who attends public spaces but simultaneously narrows it to public space projects. A consequence of such interpretation is that it assumes that all of the stakeholders engaged in public space provision and management unanimously act as urban designers; and therefore have no independent presence in the model. This can be problematic since stakeholders more often come from different and mostly contradictory origins in terms of motivation, interest, anticipation, and so on. In fact, the contested nature of public space and the conflict of interests have been mentioned in Carmona's paper. Yet, the model itself lacks to account for the complexity and nuances of power relationship among different stakeholders that ultimately lead to a collective meaning and image of a public space. In other words, the model lacks a prerequisite: the publicness of public space is challenged all along the process of place-shaping and thus the nature of public space changes.

This paper contributes to the ongoing discussions by proposing an analytical public space framework focusing on place governance - an area which has not been fully accounted for in the earlier models discussed. In doing so, it is useful to define the concept of governance, urban governance, and place governance. The term governance is used in politics and public administration to signify a shift from conventional way of governing known as government to a more efficient and effective model, a new process of governing through network of actors (Pierre, 1999, 2005; Rhodes, 2007). The shift indicates an attempt to decentralise power, question the hierarchy, and diminish the administrative role of the formal government in order to devolve authority to non-governmental institutions (Hambleton, 2015).

Governance has been referred to in different modifications such as corporate, global, environmental, participatory, managerial, and urban (Rhodes, 1997). Urban governance, in particular, is defined as the processes of control, coordination and regulation of the urban affairs; and steering urban society towards collectively defined goals (Pierre, 2005). It involves formal and informal actors, institutions, and organisations beyond the state or government; is strongly tied to the structure of power in a political system; and reflects overarching values and practices of the society (Pierre, 1999). Focusing on participatory planning, Healey (2010, p. 50) defines place governance as the 'deliberate collective activity of management and development of the place' - theorised as a way of collaboratively planning and designing places with regard to their characteristics, traits and potentials (Healey, 2015). 


\section{Public Space Governance Framework}

Informed by the earlier literature review, Figure 1 shows the proposed public space governance framework (PSGF) including major components of 1) governance structure; 2) actors and stakeholders; 3) governing tools; and 4) governing tasks.

\section{Governance structure: power, authority and stakeholders' relations}

The structure of governance is the most influential governance component that directly or indirectly affects the entire governance arrangement. Power - the way it is distributed authority and stakeholders' relations explain the structure of public space governance (Carmona, 2016a). Below four structure arrangements are explained — bearing in mind that in practice, public space governance may be a mix of two, or may transform from one shape into another over the course of time.

1) In traditional governance power is fully concentrated in the public sector (e.g. local government) (Adams \& Tiesdell, 2013). Governmental departments finance, develop, and manage the space while the private sector or local communities may or may not be given any interventionist power. The authority of intervention always remains with the government. Citizens' may indirectly be involved in decision-making process through conventional voting. Traditional governance is criticised for inefficiency, mediocre or lowquality outcomes, and under-management (Gruening, 2001).

2) In managerial governance, responsibilities of intervention and control are institutionalised and given to management agencies such as arm's-length organisations of government or semi-private entities established by government. This form of governance is also known as New Public Management (NPM) (Johnston, 2000). NPM was initially a reaction to the traditional, hierarchical, and bureaucratic administration (Gruening, 2001; O'Flynn, 2007). Using the private sector expertise and resources, and inspired by market concepts (such as demand, supply, customers, and producers) this approach is meant to bring efficiency, costeffectiveness and professional delivery to the public service conduct (Pierre, 1999). In this model, power can be concentrated in government, or devolved to the managerial agency. Users are treated as customers and their satisfaction influences the decisions made by the space management agency. Authority in such governance is hierarchical and dispersed through managerial agency and its contractors. The challenge here is to avoid or resolve the very likely clashes between the expertise and culture of the private institutions and those of the public body (Pierre, 1999).

3) In a market-based governance, public services are assumed as tradeable goods; public sector enables the private sector to provide and manage public services; and competition between service providers is encouraged (Adams \& Tiesdell, 2013). This takes place in neo-liberal contexts. Examples include privately-owned plazas and shopping malls. Public space literature refers to this as the privatisation of public spaces (Cartlidge, 2006; Kayden \& Dept. of City Planning, The Municipal Art Society of New York, 2000; Kohn, 2004; Miller, 2007). Based on the agreement between the government and the private sector, 
power and authority distribution can vary. In a privately-owned public plaza for example, the private owner usually has the right and power to control, authorise, and make decisions about eligible use and users of the space, the security, regulations etc. 


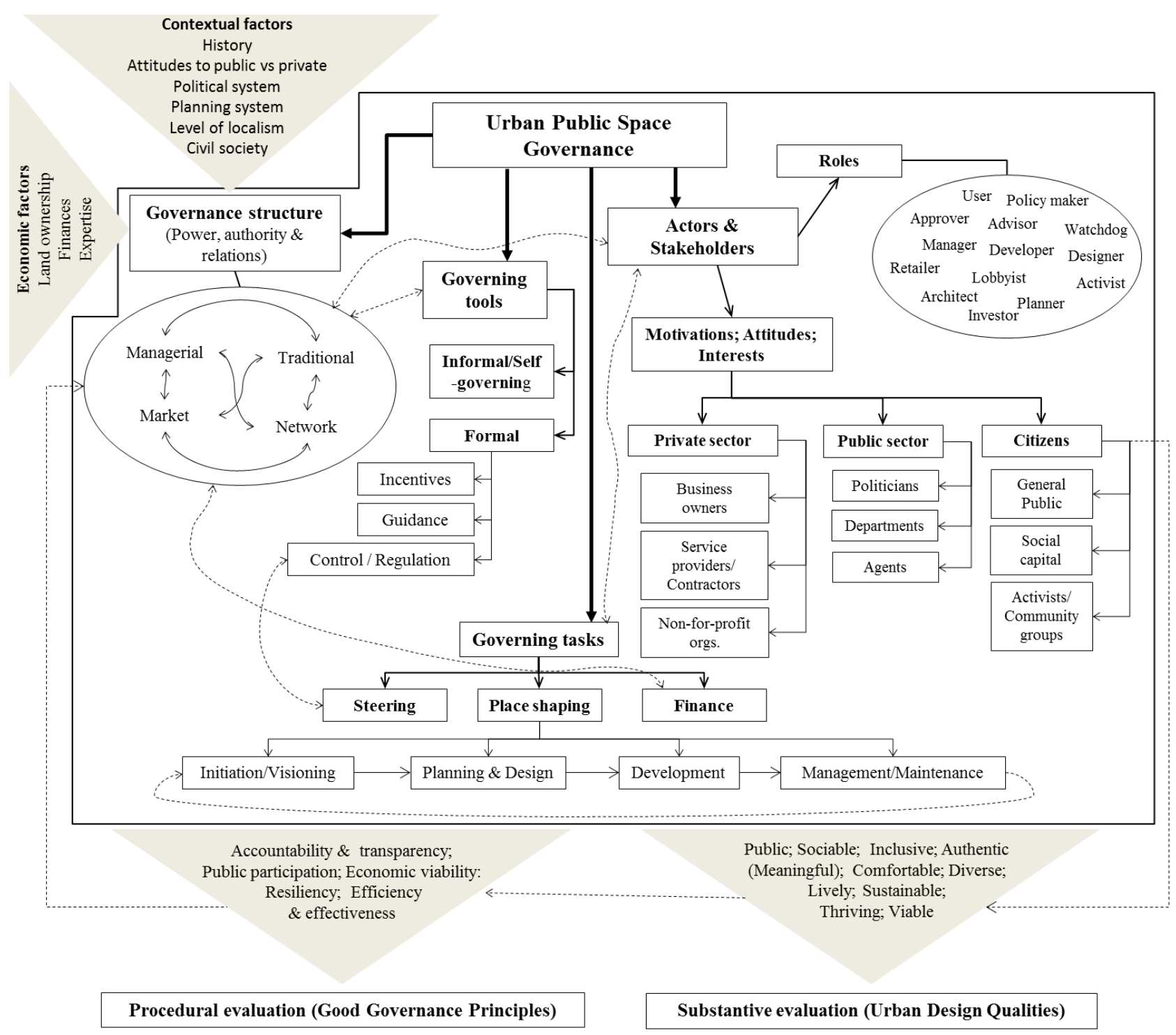

Figure 1. Public space governance framework flowchart 
4) In governance through networks, a range of stakeholders from public and private sectors, and community members collaborate to deliver quality public services. Stakeholders build their relationships on trust, voluntary collaboration, and self-organisations (Adams \& Tiesdell, 2013; Rhodes, 1997). There is no dominant power and power is distributed among stakeholders; decision-making is collective; the state enables local communities, citizens, and businesses to participate in decision making processes; and authority is disaggregated among stakeholders. Examples may include public spaces that are crowdfunded and managed by community groups or public spaces that are funded by no dominant private sector and instead funded and managed by organisations such as charities, trustees, NGOs, local communities, boards with representatives from all engaged stakeholders, or similar innovative arrangements.

\section{Actors and stakeholders}

An ontological feature of the proposed framework is that it considers public space shaping an act of multiple actors and stakeholders (beyond the public body) whose motivations, attitudes, and interests are different and perhaps contradictory. Actors and stakeholders can take one or more than one roles of manager, developer, planner, user etc. (Carmona, 2014b). Three main groups of stakeholders with distinctive institutional interest and perception are citizens (individuals), the public sector (e.g. local government), and the private sector (e.g. retailers) (Healey, 2010; Tiesdell \& Adams, 2011). Notably, these groups are not homogenous entities. A user who is also a local resident has probably different expectations to a user who is just a visitor or the management agency can also be the developer or the policy maker. Therefore, roles are transient, changeable, and may overlap.

\section{Governing tools}

Governance requires consensus, ground rules, law, and enforcement to fulfil its objectives. Depending on governance capacity and culture, level of trust among stakeholders, and the extent to which concerns of local community and marginalised voices are heard by formal government, governing tools can take different forms with various rhetorical policies (Brandtner, Höllerer, Meyer, \& Kornberger, 2016; Coaffee \& Healey, 2003; Healey, 2015).

The governing tools can be formal or informal. Incentives, guidance, and control are three categories of formal governing tools (Carmona, 2016b). These tools may be translated into masterplans, briefs, legal acts or local laws in public spaces. The applicability of each of the tools has a strong tie with the governance structure, governing tasks, and actors engaged throughout the processes of development and management. For example, while incentives are more or less to shape the physical environment, the local laws are to regulate the behavioural environment in the operation stage. Formal governing tools can be either defined through actors' collaboration and consensus or by the institution in power. In terms of level of intervention, incentives are the least interventionist and control (regulation) comes as the most interventionist tool (Carmona, 2016b).

Informal tools are those indirect means of governance that stakeholders other than formal government bring in (Salamon \& Elliott, 2002). Mitchell and Staeheli (2009) state that cultural 
rules are the grassroots of public behaviour in public spaces. Non-governmental managing agencies and the general public bring their share of informal tools (Salamon \& Elliott, 2002). Community values, aspirations, and attachments are all part of informal governing tools in public spaces (Manzo \& Perkins, 2006). In addition, the collective images people hold of a space is also a determining factor in the way they use or behave in that space (Lynch, 1960).

\section{Governing tasks}

Governance arrangements are in place for conducting activities of steering and coordinating interventions and actors towards objectives; place shaping; and providing finance for the former two tasks. Place shaping includes actions of visioning, planning, design, development, management, and maintenance of the space. These are the actions that Carmona (2014b) terms the processes of urban design or place-shaping. All of these actions are important in determining the quality of the environment. When studying governance of public spaces, it is important to understand how the ideas of development are imagined and passed from design to development and to management; how resources are marshalled; and how management works during the shifts in political and economic conditions (Adams \& Tiesdell, 2013; Healey, 2010).

\section{PSGF application to the case study public space}

The case study is South Bank Parklands (SBP) in Brisbane, capital of Australian State of Queensland. Covering 17 hectares of land, SBP is a mix of hard and soft landscaped and retail spaces that stages recreational activities, national and local celebrations, ethnic festivals, community events and outdoor markets. It is surrounded by cultural and educational institutions, art galleries, museums, and a strip of fine restaurants. It is located in walking distances to hotels, cinemas, bars, and Brisbane Convention and Exhibition Centre. SBP has won several urban design and management awards as a successful public space. It attracts around 10 million visitors annually (SBC, 2016a).

\section{Case study selection: why SBP?}

The reasons behind the case study selection are is threefold. Fist, the mainstream urban research has been dominated by studies of urban change in world cities, the branded or capital metropolises in the global north (Bell \& Jayne, 2009). This paper resonates with the call for further research in -small and medium-sized cities, to increase the generalisability of urban studies (Robinson, 2008). Brisbane, with a population of 1.2 million and a GDP equivalent to $12 \%$ of Tokyo's, counts as a medium-sized city (Commonwealth of Australia, 2015). Second, SBP has a complex and multi-facet governance and is a contested space in economic and political respects. Over the years, it has had multiple self-conscious shaping processes, certain control and management policies, and has undergone several stages of design and development. The innovative governance arrangement of a popular public space that has had the active engagement of the private sector in the management process makes SBP an atypical example that is worth researching. The multiplicity of actors and stakeholders engaged in its management and development processes, and its attractiveness to the politicians and the private sector alike provide a rich and multi-layered case study that allows the nuances of the proposed framework (Figure 1) to be tested. The practicality of first-hand data collection was the third 
ground for choosing SBP as researchers live and work in Brisbane and are familiar with the case study area and the city.

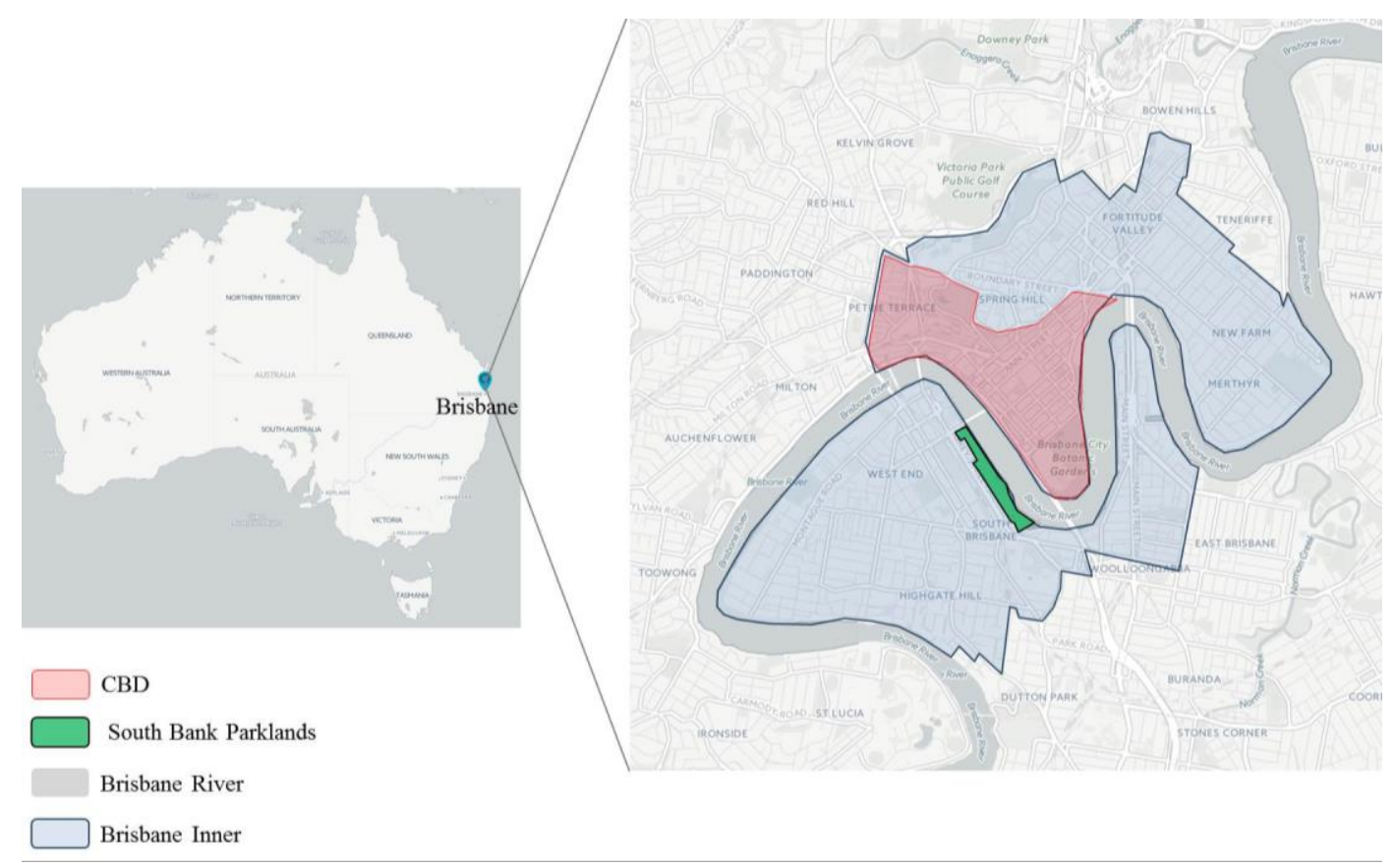

Figure 2. South Bank Parklands is located in inner city of Brisbane- Source of the base maps: AURIN, 2016.

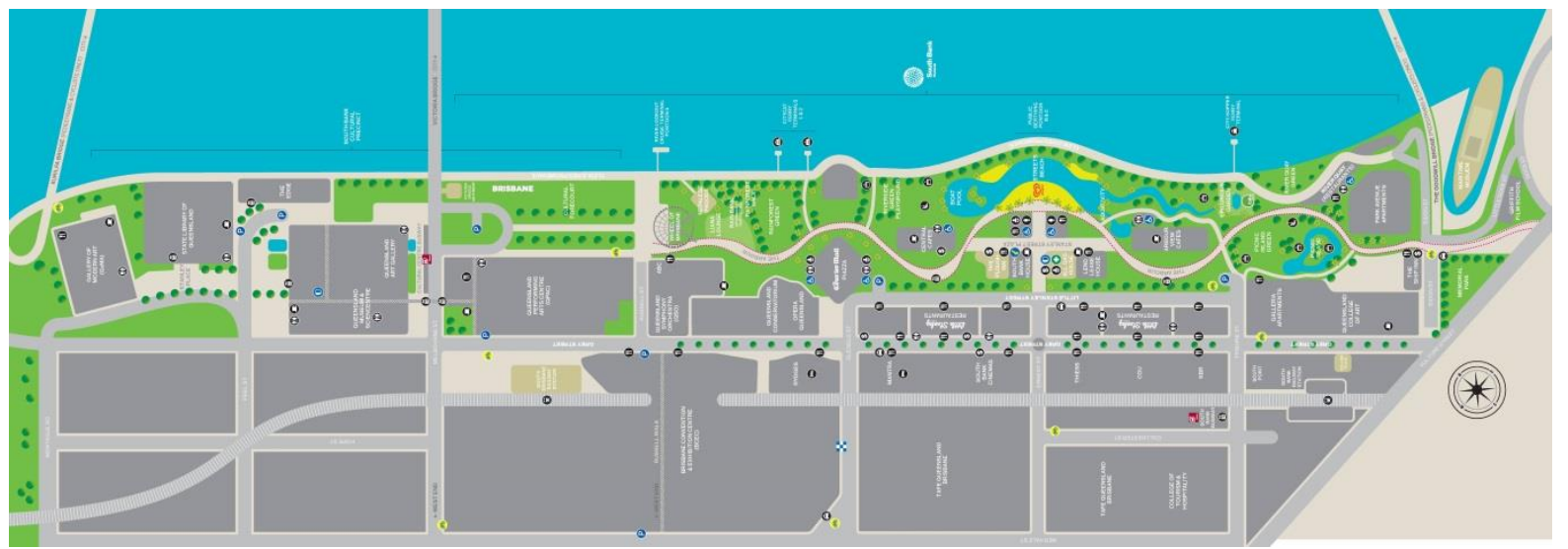

Figure 3 South Bank Parklands Map - Source: Visit Brisbane (2017).

A combination of semi-structured interviews and document analysis was conducted to study SBP and understand its place governance structure. 10 Interviews were conducted with previous and present managers, planners, advisors, and event organisers (based in different organizations and involved at different times). Interview schedules were adjusted based on the role each person or institution has had in developing and managing SBP. Moreover, relevant policy documents and texts consisting of both electronic and printed material were examined. Master plans of South Bank, South Bank Corporation Act (ABCA) 1989 and its amendments, annual reports of South Bank Corporation, and websites of Queensland Government, Brisbane City Council and South Bank Corporation were among the resources. 


\section{The contextual factor and place-shaping history of SBP}

SBP was originally a meeting, hunting and gathering place for indigenous people (Sanderson, 2003). After European free settlement in Brisbane in 1840s, it became the main port of Brisbane In 1930s South Bank turned to a bustling industrial area with wharves, markets, dance halls, and theatres around (SBC, 2016b). However, after World War II, the area started declining; and by 1984 it was a degraded place in the public eye (SBC, 2016b).

The contemporary development at South Bank dates back to 1980s when Brisbane was selected to host the World Exposition 1988 (Expo 88). The decision to mount the exposition was reached after long Figure 4. Aerial view of the Expo 88 negotiations that involved the state and Photo: () The State of Queensland (Department of the federal governments and lobbyists (Carroll,

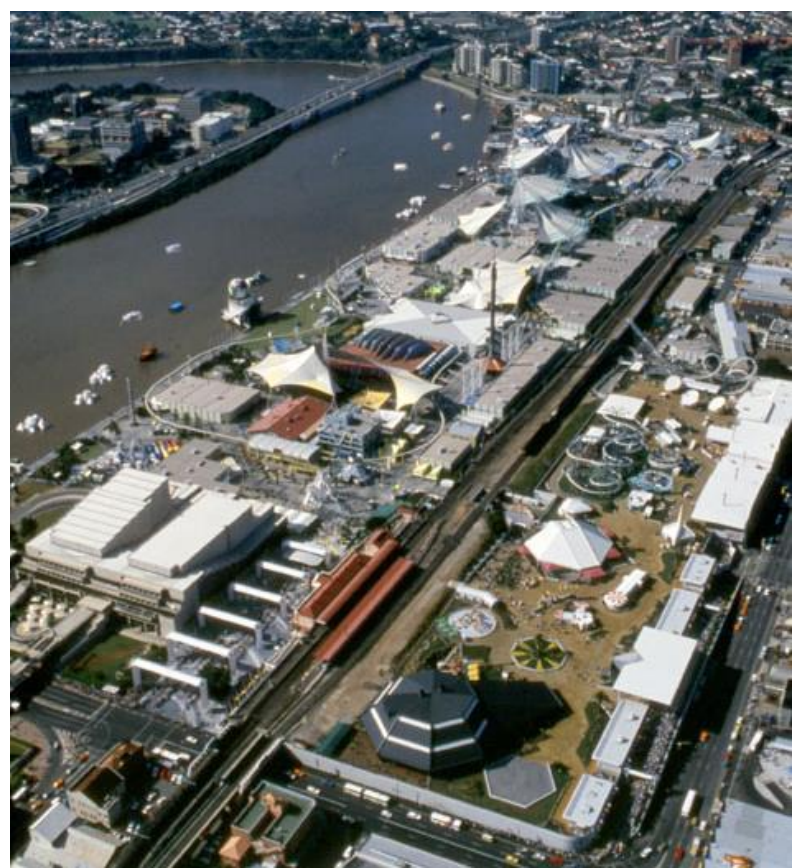
Premier and Cabinet) 2017 1989). At that time, Brisbane authorities were trying to put the city on the world map. State government's initial plan after the Expo was to sell off the land to the private corporations to compensate the cost. The success of the Expo in attracting people to the area, however, helped reposition the urban locale in the mental map of the citizens and the private sector (as major projects intend to do Healey, 2010). The public then wanted the ambiance of the Expo to continue (SBC Manager B) and objected the proposed plan that would privatise and develop the entire area similar to the CBD in the north (Noble, 2001). Eventually, under the public's pressure 17 out of 40 hectares of the land was saved for a series of public open spaces. The rest of the site went under medium density mixed-use development with a focus on hospitality, food and beverage (SBC former advisor).

South Bank was revitalised as part of a new direction that Brisbane had taken in competition with other Australian cities, Sydney, Melbourne, and Adelaide to attract more economic investment and skilled immigrants (SBC Manager B).
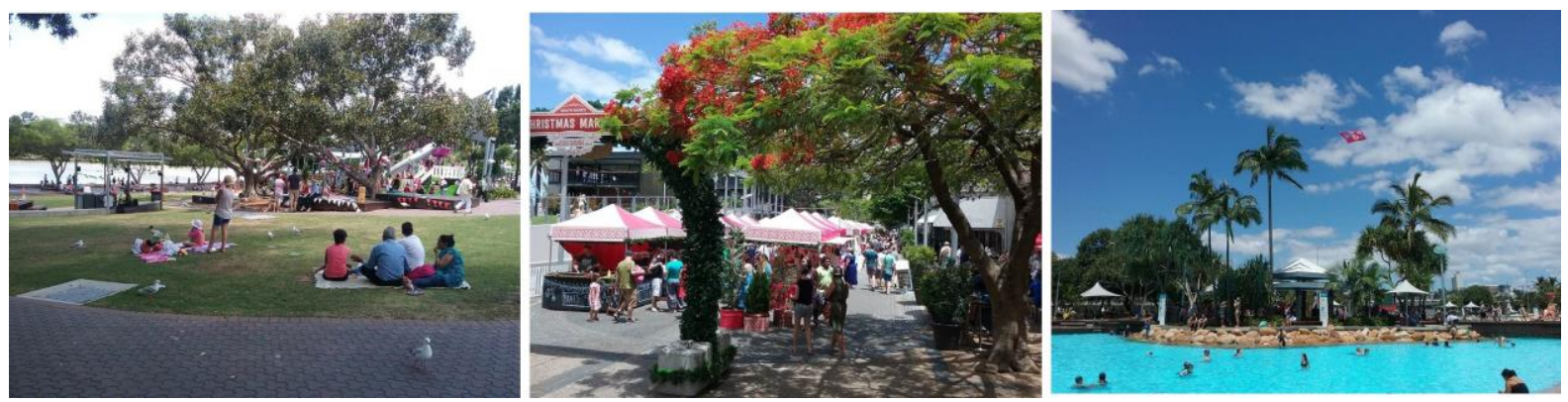

Figure 5. South Bank Parklands is made up of a variety of soft and hard open spaces. Photos: Hadi Zamanifard, 2016 


\section{Governance structure in SBP}

Analysis of power, authority and the stakeholders' relations in SBP indicates two different governance structures before and after July 2013:

\section{Before July 2013}

Between 1989 and 2013, SBP, as part of the 40-hectare South Bank Corporation area, was developed and managed by South Bank Corporation (SBC), a statutory body constituted by Queensland Parliament through South Bank Corporation Act 1989 (SBCA). The SBP governance structure in this era can be described as a combination of managerial and traditional models. In this period, SBC was in charge of assessing development proposals, marketing for potential businesses and financial arrangements, everyday management of the precinct including arranging for security and cleaning, regulations, accommodating events, and managing commercial and retail leaseholds (Queensland Government, 1989).

SBC is governed by a board consists of 7 to 9 members who are experts in financial, property management, community service, architecture, and planning. State government can have two representatives and the $\mathrm{BCC}$ two and the rest are from the private sector nominated by the Minister and appointed by the cabinet (Queensland Government, 1989). According to the SBCA, the Minister approves minor changes to the approved development plan and can give new directions to SBC with regard to the public interest if necessary (Queensland Government, 1989). State Government as the land owner has the highest authority over the land, and provides finance for the development and management.

SBC brought expertise to the management and development process; concentrated on better outcomes; and provided flexibility for achieving quality design and management (Ganis, Minnery, \& Mateo-Babiano, 2014; Zamanifard et al., 2016). The integrated management and power of SBC; its availability for the local businesses (SBC office is located in the area); and its organisational culture that embraced collaboration with the investors in the area (acting as real estate manager) provided governance capacity for the local businesses (SBC Manager A); which was pointed out a few times during interviews:

... [S]BC had a very strong working relationships with most stakeholders. The south bank corporation initiated the formation of an organisation called ... Business South Bank which was very much an attempt to develop and network of both small and large businesses in South Bank who had a direct stake in the success particularly in economic success. It was like a little chamber of commerce (SBC Manager B).

However, the expert and top-down based approach of the SBC left little room for the public participation in decision making processes (urban activist A). SBCA had required the Corporation to consult with community when preparing or amending the development plans. In the preliminary phases of development, SBC displayed the proposed masterplans and received public feedback (Ganis et al., 2014). SBC had the power to consider the public's comments or to refuse them. The minister would make the final decision in this respect (Queensland Government, 1989). Nonetheless, no specific strategy was developed to effectively provide governance capacity for the public engagement in decision-making 
processes. Public consultation is sharing of information but not necessarily of power (Sarkissian, Cook, \& Walsh, 1997). An exemplar outcome of this flawed approach was the disconnection between SBP and the southern neighbourhoods. It has been argued that South Bank development has created a totally different identity with no appropriate visual and functional linkage to the neighbouring southern suburbs, namely South Brisbane and West End (Lloyd \& Auld, 2003). Some critiques have argued that SBC was not serving residents of the neighbouring areas and therefore was not contributing to enhancing the quality of life for the locals (Lloyd \& Auld, 2003).

Furthermore, the rivalry between SBC and $\mathrm{BCC}$ in controlling the precinct mirrors the SBP political economy. According to SBC Annual Report 2016-2017, the Corporation had a total yearly income of more than $\$ 18$ million from services it provided and an estimation of $\$ 750$ million of assets (SBC, 2017). The SBC approach has been to benefit from pedestrians' economy and visitors that willingly spend money rather than directly charging them highlighting the significance of the parklands in drawing people to the area:

... [W] could charge for the pool, we could charge for the toilets or BBQs, we don't do any of that, because we think the better way is to extract the revenues from people willingly spending money on coffees or meals, so it's almost like a voluntary kind of taxation system (SBC Manager A).

\section{After July 2013}

The SBCA denotes that SBC may cease to exist and all the corporation responsibilities may be transferred to normal departments within the local and state governments when the development of the area is complete. Part of this transfer happened in 2013 when the managerial responsibilities of the SBP were given to BCC. Upon this transfer the autonomy of SBC and its integrated management of the precinct were abolished. SBC was reluctant to give up the management reasoning that a section of SBP (the south point) was not fully developed yet (SBC, 2016); and BCC would not be able to fulfil the objects stated in SBCA.

Since July 2013, BCC regulates and manages SBP and approves development applications within the precinct. BCC has also used NPM by establishing City Parklands Transition Services Pty. Ltd. This entity is responsible for managing everyday routines of SBP such as maintenance, cleaning, and security. City Parklands reports to BCC and SBC Board (CPM, 2016). Brisbane Marketing (BM) - BCC's marketing and economic arm - is tasked with activation of the area. Brisbane Marketing board's members are mostly from successful local businesspersons. The board assigns the strategic directions for the BM under supervision of the mayor of Brisbane (Brisbane Marketing, 2016). Using public spaces and pedestrian flow to boost the economy and empower businesses is one of the BM's objectives.

So far, although BCC is by law a public body presumably supposed to involve the local community in the decision-making processes, there is no evidence that $\mathrm{BCC}$ is taking a different approach towards citizen engagement in public space governance than SBC did. The socio-spatial importance of SBP, strong presence of the SBC, and large businesses have all left little room for public participation in decision-making. Current SBP governance structure is a mix of managerial and traditional models leaning towards market-based structure in 
competition with SBC as the BM's objective is to attract more visitors and tourists to the precinct (BM, 2017). The shift towards market structure has given the private sector a larger platform and louder voice.

\section{Actors and stakeholders in SBP}

Table 2 offers a summary of diverse actors and stakeholders, in both individual and institutional forms, involved with SBP shaping and managing processes and their roles and motivations. Some of the actors have already been discussed in the governance structure item.

Table 2. Roles and motivations of stakeholders involved in South Bank governance

\begin{tabular}{|c|c|c|c|c|}
\hline & & $\begin{array}{l}\text { Actors and } \\
\text { stakeholders }\end{array}$ & Roles & Motivations \\
\hline \multirow{13}{*}{ 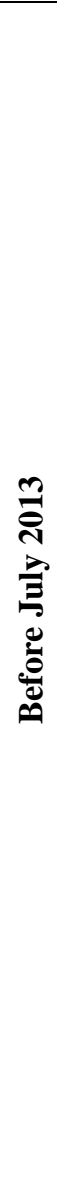 } & & $\begin{array}{l}\text { State Parliament } \\
\text { (SP) }\end{array}$ & Legaliser; Approver & $\begin{array}{l}\text { Administrative obligation; Better } \\
\text { public service management; Public } \\
\text { interest; Political aspirations; Growth in } \\
\text { local economy }\end{array}$ \\
\hline & & $\begin{array}{l}\text { The then-mayor of } \\
\text { Brisbane (1985- } \\
\text { 1991) }\end{array}$ & Open space advocate & Public service; Public interest; \\
\hline & & $\begin{array}{l}\text { State Government } \\
(\mathrm{SG})\end{array}$ & $\begin{array}{l}\text { Owner; Supplier; Policy- } \\
\text { maker; Supervisor }\end{array}$ & $\begin{array}{l}\text { Administrative obligation; Political } \\
\text { aspirations; Growth in local economy }\end{array}$ \\
\hline & & $\begin{array}{l}\text { Premier (Deputy } \\
\text { Premier) }\end{array}$ & $\begin{array}{l}\text { Approver; Power } \\
\text { administrator }\end{array}$ & $\begin{array}{l}\text { Administrative obligation; Political } \\
\text { aspirations }\end{array}$ \\
\hline & & South Bank & Regulator; Developer; & Administrative obligation; Public \\
\hline & & Corporation (SBC) & Manager; Approver & $\begin{array}{l}\text { interest; Financial revenue; Creating } \\
\text { quality space }\end{array}$ \\
\hline & & Brisbane City & Consultant; Governing & Administrative obligation; Growth in \\
\hline & & Council (BCC) & board member & local economy; Public interest; \\
\hline & & $\begin{array}{l}\text { Design advisory } \\
\text { panel }\end{array}$ & Adviser & Applying urban design principles \\
\hline & & Griffith University & $\begin{array}{l}\text { Developer; Supplier; } \\
\text { User }\end{array}$ & Public value; Educational branding \\
\hline & & $\begin{array}{l}\text { Planning and design } \\
\text { firms }\end{array}$ & Planner/ designer & Professionalism; Design excellency \\
\hline & & $\begin{array}{l}\text { Businesses and } \\
\text { retailers }\end{array}$ & Investor; User & Maximising revenues \\
\hline & & $\begin{array}{l}\text { General public } \\
\text { (civil society) }\end{array}$ & User; Supervisor & $\begin{array}{l}\text { Civic pride; Better public life; Civic } \\
\text { rights; Social responsibility }\end{array}$ \\
\hline \multirow{5}{*}{ 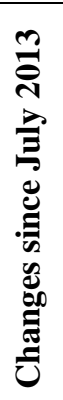 } & \multirow{2}{*}{ 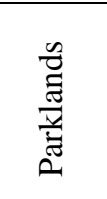 } & $\begin{array}{l}\text { South Bank } \\
\text { Corporation }\end{array}$ & Supervisor; Consultant & $\begin{array}{l}\text { Administrative obligation; Quality } \\
\text { space }\end{array}$ \\
\hline & & $\begin{array}{l}\text { Brisbane City } \\
\text { Council }\end{array}$ & Regulator; Manager; & $\begin{array}{l}\text { Governing integration; Unity in public } \\
\text { space management }\end{array}$ \\
\hline & \multirow{3}{*}{ 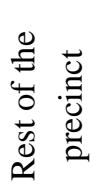 } & South Bank & Regulator; Manager; & Administrative obligation; Financial \\
\hline & & Corporation & Developer & revenues; Growth in local economy \\
\hline & & $\begin{array}{l}\text { Brisbane City } \\
\text { Council }\end{array}$ & Approver & $\begin{array}{l}\text { Urban management integration; } \\
\text { Growth in local economy }\end{array}$ \\
\hline
\end{tabular}

Chronologically discussing, civil society and the then-mayor of Brisbane, Sallyanne Atkinson, were at the centre of the push for a public space after Expo 88 (Noble, 2001). The state 
parliament, and the then-premier (Michael Ahern), had major roles in establishing and legalising SBC and outlining objectives, principles, and policies for the development and management of the precinct (Queensland Government, 1989).

In 1990s and 2000s, a design advisory panel alongside with broader architecture and planning community in Brisbane urged change in the direction of development in South Bank. In 1996, when the second masterplan for the area was going to be prepared, the panel advised using urban design principles such as connectivity, street life, human scale, walkability and so on (SBC, 2016b; SBC former advisor).

Other stakeholders were fairly involved or were brought in as investors. Griffith University as a major stakeholder and the owner of a few buildings attracts 3400 students to the area (Griffith University, 2016). Retailers and local businesses play an important role in enhancing vibrancy of the environment. They also affect the managerial decisions in particular those of security, events, and activities (SBC Manager A).

\section{Governing tools in SBP}

Governance in SBP has been exercised through top-down, formal and technocratic instruments. South Bank Corporation Act 1989 and its later amendments have been sources from which principles, regulations and other governing tools have been extracted. In addition, principles and visions of development in the area have been spelled in two masterplans (1991-1996 and 1997-2001) mostly through performance design guidelines and urban design principles. Furthermore, prescriptive guidance and control of the physical and functional environment is undertaken through a plan called Approved Development Plan. SBC is driven by a key performance indicator (KPI) defined by its board (SBC Manager B). In terms of public space usage, local by-laws have been in place and enforced by SBC and BCC before and after 2013 respectively.

In addition, viable development and management has constantly been an objective and a major policy governing most decisions in the precinct as a manager in SBP mentions:

... [O]ur KPI was [to] deliver community events, deliver something for everyone and we maintain on those kind of criteria, not our balance sheet, they [State Government] want us to be self-sustained, so our balance sheet has to be healthy and has to produce enough to pay for very expensive things that have to happen here ... there was sort of an in-built kind of belt into the process of having that financial discipline saying that you got a loan to pay you got to make enough money to pay your wages and your staff and all of those things (SBC Manager A)

An influential informal governing tool in SBP has been the widespread image that the area is a recreational and touristy spot with fine restaurants. Consumption and recreation are two major elements in promotional contents used by BCC, Brisbane Marketing, and SBC (BM, 2016).

\section{Governing tasks in SBP}

Governance in SBP, as an 'all-of-a-piece urban design' (Lang, 2005, p. 27), incorporates initiation, design, development, and management activities. From the beginning of its development, SBP has repeatedly undergone one or some of these activities. First attempts of 
design, development and management were completely motivated and implemented by SBC. The second round of development, however, was accompanied by larger participation of stakeholders and resulted in fundamental changes in visioning. The major parts of development in SBP is complete by now and most of the governance activities includes managing the spaces in use (SBC Manager A).

\section{Lessons learnt from SBP and concluding comments}

This paper built upon a gap in the public space literature as existing models fail in explaining the complexity of today's public space shaping and managing processes. It argued that public space governance needs to be brought to the centre of public space debates - with special attention to questions of who has the rights to the space and how priorities are defined. In order to contribute to the discourse of public space governance, the paper borrowed from governance theories; and conceptualised a public space governance framework (PSGF). The proposed framework provided a holistic and dynamic approach and resonated with the theories that define public space shaping as a continuous process involving actors and stakeholders beyond the formal or self-conscious players (Carmona, 2014b). It argued that the governance is affected by the culture and perceptions of these stakeholders; affects all the management and development tasks; and is implemented through not only formal but also informal instruments.

The PSGF was then applied to South Bank Parklands (SBP), a flagship and popular public space in Brisbane, Australia. The proposed framework in this paper permitted a systematic analysis of governance in a contested public space in a neo-liberal democratic context. The case study did not confirm the assumption in the literature that public space is in decline because of the role of private sector in its governance arrangement (see Kohn, 2004; Madanipour, 2003; Sorkin, 1992). Findings rather showed that 'institutional creativity' (Adams \& Tiesdell, 2013) in SBP — South Bank Corporation — created economically viable quality public spaces which are very popular. Nonetheless, the framework helped identify a potential problem with the case study public space. That is, there is a move towards market-based governance that may lead to a decrease in the role of public in the governance of the place despite the fact that a public body (BCC) is in charge of the routine affairs. The reason lies in the rivalry between $\mathrm{SBC}$ and $\mathrm{BCC}$ and the influence of the political economy of the precinct as a profitable precinct (see Moore, 2013).

There are avenues for further research. First, the framework needs to be tested in different public spaces in terms of dominant actors (community based management for example). Another interesting avenue can be studying the impacts of the actors' behaviour in intangible aspect and the spirit of governance in a public space, given that actors can have multiple roles with different motivations. Furthermore, the evaluation aspect of the public space governance framework needs to be elaborated and tested in various public space typologies to scrutinize the variety of governance models and their performances in different contexts.

\section{Note}

1. In this paper, a public space is defined as an outdoor destination that is accessible to all members of society free-of-cost. Such space is potentially sociable and can be used by 
people for a range of activities like sitting, relaxation, watching, wandering or just passing through.

\section{Acknowledgement}

This research did not receive any specific grant from funding agencies in the public, commercial, or not-for-profit sectors.

\section{References}

1. Adams, D., \& Tiesdell, S. (2013). Shaping Places: Urban Planning, Design and Development. Routledge.

2. Amin, A. (2008). Collective culture and urban public space. City, 12(1), 5-24. https://doi.org/10.1080/13604810801933495

3. Banerjee, T. (2001). The future of public space: beyond invented streets and reinvented places. Journal of the American Planning Association, 67(1), 9-24.

4. Bell, D., \& Jayne, M. (2009). Small Cities? Towards a Research Agenda. International Journal of Urban and Regional Research, 33(3), 683-699. https://doi.org/10.1111/j.1468-2427.2009.00886.x

5. BM. (2016). Tourism Precincts. Retrieved September 18, 2016, from http://www.choosebrisbane.com.au/invest/business-precincts/tourismprecincts?sc_lang=en-au

6. BM. (2017). What We Do. Retrieved January 10, 2018, from http://www.choosebrisbane.com.au/corporate/brisbane-marketing/what-wedo?sc_lang=en-au

7. Boyer, M. C. (1993). The city of illusion: New York's public places. In P. L. Knox (Ed.), The Restless Urban Landscape (pp. 111-126). N.J: Prentice Hall: Englewood Cliffs.

8. Brandtner, C., Höllerer, M. A., Meyer, R. E., \& Kornberger, M. (2016). Enacting governance through strategy: A comparative study of governance configurations in Sydney and Vienna. Urban Studies. https://doi.org/10.1177/0042098015624871

9. Brill, M. (1989). Transformation, Nostalgia, and Illusion in Public Life and Public Place. In I. Altman \& E. H. Zube (Eds.), Public Places and Spaces (pp. 7-29). New York: Plenum Press. https://doi.org/10.1007/978-1-4684-5601-1_2

10. Burton, E., \& Mitchell, L. (2006). Inclusive urban design: Streets for life. Routledge.

11. Carmona, M. (2010). Contemporary public space: critique and classification, part one: critique. Journal of Urban Design, 15(1), 123-148.

12. Carmona, M. (2014a). Re-theorising contemporary public space: a new narrative and a new normative. Journal of Urbanism: International Research on Placemaking and Urban Sustainability, 8(4), 1-33. https://doi.org/10.1080/17549175.2014.909518

13. Carmona, M. (2014b). The Place-shaping Continuum: A Theory of Urban Design Process. Journal of Urban Design, 19(1), 2-36. https://doi.org/10.1080/13574809.2013.854695 
14. Carmona, M. (2016a). Design governance: theorizing an urban design sub-field. Journal of Urban Design, O(0), 1-26. https://doi.org/10.1080/13574809.2016.1234337

15. Carmona, M. (2016b). The formal and informal tools of design governance. Journal of Urban Design, 1-36. https://doi.org/10.1080/13574809.2016.1234338

16. Carmona, M., De Magalhães, C., \& Hammond, L. (2008). Public space: the management dimension. Routledge.

17. Carmona, M., \& Wunderlich, F. (2012). Capital spaces: the multiple complex public spaces of a global city. Abingdon, Oxon; New York: Routledge.

18. Carroll, P. (1989). The origins of Expo 88. Australian Journal of Public Administration, 48(1), 41-52.

19. Cartlidge, D. P. (2006). Public private partnerships in construction. New York; London: Taylor \& Francis.

20. Coaffee, J., \& Healey, P. (2003). "My Voice: My Place": Tracking Transformations in Urban Governance. Urban Studies, 40(10), 1979-1999. https://doi.org/10.1080/0042098032000116077

21. Commonwealth of Australia,. (2015). State of Australian Cities 2014-2015, Progress in Australian Regions. Department of Infrastructure and Regional Development.

22. Cuthbert, A. R. (2006). The form of cities: Political Economy and Urban Design. UKCarlton, Aus: Malden MA-Oxford.

23. De Magalhães, C. (2010). Public Space and the Contracting-out of Publicness: A Framework for Analysis. Journal of Urban Design, 15(4), 559-574. https://doi.org/10.1080/13574809.2010.502347

24. De Magalhães, C., \& Carmona, M. (2009). Dimensions and models of contemporary public space management in England. Journal of Environmental Planning and Management, 52(1), 111-129. https://doi.org/10.1080/09640560802504704

25. De Magalhães, C., \& Freire Trigo, S. (2017). Contracting out publicness: The private management of the urban public realm and its implications. Progress in Planning, 115(Supplement C), 1-28. https://doi.org/10.1016/j.progress.2016.01.001

26. Ellin, N. (1999). Postmodern Urbanism. Princeton Architectural Press.

27. Francis, M. (1989). Control as a Dimension of Public-Space Quality. In I. Altman \& E. H. Zube (Eds.), Public Places and Spaces (pp. 147-172). Boston, MA: Springer US. https://doi.org/10.1007/978-1-4684-5601-1_7

28. Franck, K. A., \& Paxson, L. (1989). Women and Urban Public Space: Research, Design, and Policy Issues. In I. Altman \& E. H. Zube (Eds.), Public places and spaces. New York: Plenum Press.

29. Friedmann, J. (2010). Place and Place-Making in Cities: A Global Perspective. Planning Theory \& Practice, 11(2), 149-165. https://doi.org/10.1080/14649351003759573

30. Ganis, M., Minnery, J., \& Mateo-Babiano, D. (2014). The Evolution of a Masterplan: Brisbane's South Bank, 1991-2012. Urban Policy and Research, 32(4), 499-518. https://doi.org/10.1080/08111146.2013.877390

31. Goldsteen, J. B., \& Elliott, C. C. (1994). Designing America: Creating urban identity: a primer on improving US cities for a changing future using the project approach to 
the design and financing of the spaces between buildings. Van Nostrand Reinhold Company.

32. González, S., \& Healey, P. (2005). A Sociological Institutionalist Approach to the Study of Innovation in Governance Capacity. Urban Studies, 42(11), 2055-2069. https://doi.org/10.1080/00420980500279778

33. Gruening, G. (2001). Origin and theoretical basis of new public management. International Public Management Journal, 4(1), 1-25. https://doi.org/10.1016/S10967494(01)00041-1

34. Hajer, M., \& Reijndorp, A. (2001). In search of new public domain. NAi Rotterdam.

35. Hambleton, R. (2015). Leading the Inclusive City: Place-Based Innovation for a Bounded Planet. Bristol and Chicago: Policy Press.

36. Harvey, D. (1989). From Managerialism to Entrepreneurialism: The Transformation in Urban Governance in Late Capitalism. Geografiska Annaler. Series B, Human Geography, 71(1), 3-17. https://doi.org/10.2307/490503

37. Healey, P. (2010). Making better places: the planning project in the twenty-first century. Palgrave Macmillan.

38. Healey, P. (2015). Civic capacity, place governance and progressive localism. In S. Davoudi \& A. Madanipour (Eds.), Reconsidering localism (pp. 105-125).

39. Inam, A. (2002). Meaningful Urban Design: Teleological/Catalytic/Relevant. Journal of Urban Design, 7(1), 35-58. https://doi.org/10.1080/13574800220129222

40. Johnston, J. (2000). The New Public Management in Australia. Administrative Theory \& Praxis, 22(2), 345-368. https://doi.org/10.1080/10841806.2000.11643455

41. Kayden, J. S., \& Dept. of City Planning, The Municipal Art Society of New York,. (2000). Privately owned public space: the New York City experience. John Wiley \& Sons.

42. Kent, E. (2013). Toward Place Governance: What If We Reinvented Civic Infrastructure Around Placemaking? Retrieved January 14, 2017, from https://www.pps.org/reference/toward-place-governance-civic-infrastructureplacemaking/

43. Kohn, M. (2004). Brave new neighborhoods: The privatization of public space. Psychology Press.

44. Lang, J. (2005). Urban Design: a Typology of Procedures and Products. Architectural Press.

45. Langstraat, F., \& Melik, R. V. (2013). Challenging the "end of public space": a comparative analysis of publicness in British and Dutch urban spaces. Journal of Urban Design, 18(3), 429-448. https://doi.org/10.1080/13574809.2013.800451

46. Lefebvre, H. (1991). The production of space (Vol. 142). Oxford Blackwell.

47. Lefebvre, H., \& Enders, M. J. (1976). Reflections on the Politics of Space. Antipode, $8(2), 30-37$.

48. Light, A., \& Smith, J. M. (1998). Philosophy and Geography II: The Production of Public Space. Rowman \& Littlefield.

49. Lofland, L. H. (1989). Social life in the public realm: a review. Journal of Contemporary Ethnography, 17(4), 453-482. https://doi.org/10.1177/089124189017004004 
50. Loukaitou-Sideris, A., \& Banerjee, T. (1993). The Negotiated Plaza: Design and Development of Corporate Open Space in Downtown Los Angeles and San Francisco. Journal of Planning Education and Research, 13(1), 1-12. https://doi.org/10.1177/0739456x9301300103

51. Low, S., \& Smith, N. (2006). The Politics of Public Space. Routledge.

52. Lynch, K. (1960). The Image of the City. MIT Press.

53. Madanipour, A. (2003). Public and private spaces of the city. Routledge.

54. Madanipour, A. (2010). Whose public space?: international case studies in urban design and development. London: Routledge.

55. Malone, K. (2002). Street life: youth, culture and competing uses of public space. Environment and Urbanization, 14(2), 157-168.

56. Manzo, L. C., \& Perkins, D. D. (2006). Finding Common Ground: The Importance of Place Attachment to Community Participation and Planning. Journal of Planning Literature, 20(4), 335-350. https://doi.org/10.1177/0885412205286160

57. Miller, K. F. (2007). Designs on the public: the private lives of New York's public spaces. Minneapolis: University of Minnesota Press.

58. Minton, A. (2006). "What kind of world are we building." The Privatisation of Public Space. RICS.

59. Mitchell, D. (1995). The End of Public Space?People's Park, Definitions of the Public, and Democracy. Annals of the Association of American Geographers, 85(1), 108-133. https://doi.org/10.1111/j.1467-8306.1995.tb01797.xa

60. Mitchell, D. (2003). The right to the city: Social justice and the fight for public space. Guilford Press.

61. Mitchell, D., \& Staeheli, L. A. (2009). Public Space. In International encyclopedia of human geography (pp. 511-516). Amsterdam, Boston, London, New York: Elsevier.

62. Moore, T. (2013, March). South Bank Corporation to "pay their fair share." Retrieved October 20, 2016, from http://www.brisbanetimes.com.au/queensland/south-bankcorporation-to-pay-their-fair-share-20130326-2gsi3.html

63. Noble, L. (2001). South Bank Dreaming. Architecture Australia, 90(5).

64. O’Flynn, J. (2007). From New Public Management to Public Value: Paradigmatic Change and Managerial Implications. Australian Journal of Public Administration, 66(3), 353-366. https://doi.org/10.1111/j.1467-8500.2007.00545.x

65. Pierre, J. (1999). Models of Urban Governance: The Institutional Dimension of Urban Politics. Urban Affairs Review, 34(3), 372-396. https://doi.org/10.1177/10780879922183988

66. Pierre, J. (2005). Comparative Urban Governance Uncovering Complex Causalities. Urban Affairs Review, 40(4), 446-462. https://doi.org/10.1177/1078087404273442

67. Pierre, J. (2014). Can Urban Regimes Travel in Time and Space? Urban Regime Theory, Urban Governance Theory, and Comparative Urban Politics. Urban Affairs Review, 50(6), 864-889. https://doi.org/10.1177/1078087413518175

68. Pospech, P. (2013). The Urban Public Space: An Interpretative Approach. Sociologicky Casopis; Prague, 49(1), 75-100.

69. PPS. (2000). How to Turn a Place Around: A Handbook for Creating Successful Public Spaces. USA: Project for Public Spaces. 
70. PPS. (2015). What is Placemaking? Retrieved from http://www.pps.org/reference/what_is_placemaking/

71. Queensland Government,. South Bank Corporation Act 1989 (1989).

72. Rakodi, C. (2003). Politics and performance: the implications of emerging governance arrangements for urban management approaches and information systems. Habitat International, 27(4), 523-547. https://doi.org/10.1016/S01973975(03)00004-3

73. Rhodes, R. A. W. (1997). Understanding governance: Policy networks, governance, reflexivity and accountability. Open University Press. Retrieved from http://eprints.soton.ac.uk/336524/

74. Rhodes, R. A. W. (2007). Understanding Governance: Ten Years On. Organization Studies, 28(8), 1243-1264. https://doi.org/10.1177/0170840607076586

75. Robinson, J. (2008). Developing Ordinary Cities: City Visioning Processes in Durban and Johannesburg. Environment and Planning A: Economy and Space, 40(1), 74-87. https://doi.org/10.1068/a39127

76. Ruhanen, L., Scott, N., Ritchie, B., \& Tkaczynski, A. (2010). Governance: a review and synthesis of the literature. Tourism Review, 65(4), 4-16. https://doi.org/10.1108/16605371011093836

77. Salamon, L. M., \& Elliott, O. V. (2002). The tools of government: A guide to the new governance. Oxford University Press.

78. Sanderson, R. (2003). Queensland shows the world: Regionalism and modernity at Brisbane's world expo '88. Journal of Australian Studies, 27(79), 65-75.

79. Sarkissian, W., Cook, A., \& Walsh, K. (1997). What is community participation? In Community Participation in Practice: A Practical Guide. Murdoch University, Western Australia: ISTP Publications.

80. SBC. (2016a). Awards. South Bank Corporation. Retrieved September 18, 2016, from http://southbankcorporation.com.au/about-us/awards/

81. SBC. (2016b). Our Heritage and Milestones. South Bank Corporation. Retrieved September 18, 2016, from http://southbankcorporation.com.au/about-us/our-heritageand-milestones/

82. SBC. (2017). South Bank Corporation Annual Report 2016 - 2017. South Bank, Qld: South Bank Corporation.

83. Schneekloth, L. H., \& Shibley, R. G. (1995). Placemaking: The art and practice of building communities. New York: Wiley.

84. Sennett, R. (1992). The fall of public man. New York: WW Norton \& Company.

85. Smith, N., \& Low, S. (2006). Introduction: The Imperative of Public Space. In S. Low \& N. Smith (Eds.), The Politics of Public Space (pp. 1-16). Routledge.

86. Sorkin, M. (1992). Variations on a theme park: The new American city and the end of public space. Macmillan.

87. Stevens, Q. (2009). "Broken" public spaces in theory and in practice. Town Planning Review, 80(4-5), 371-392. https://doi.org/10.3828/tpr.2009.3

88. Stoker, G. (1998). Governance as theory: five propositions. International Social Science Journal, 50(155), 17-28. https://doi.org/10.1111/1468-2451.00106

89. Tibbalds, F. (1992). Making People Friendly Towns. UK: Longman Group. 
90. Tiesdell, S., \& Adams, D. (2011). Urban design in the real estate development process. Hoboken, N.J: Wiley-Blackwell.

91. Webster, C. (2007). Property rights, public space and urban design. Town Planning Review, 78(1), 81-101.

92. Worpole, K., \& Knox, K. (2008). The social value of public spaces. Joseph Rowntree Foundation.

93. Zamanifard, H., Alizadeh, T., Coiacetto, E., \& Sipe, N. (2016). Why Some Places Do Better than Others: A Closer Look at Urban Public Space Management. Presented at the 9th International Urban Design Conference, Canberra. 